\title{
Pengembangan Kemampuan Berpikir Kritis Mahasiswa Melalui Penerapan Model Learning Cycle
}

\section{Developingthe Students Critical Thinking Ability ThroughThe Implementation Of Learning Cycle Model}

\author{
Luthpi Safahi $^{1^{*}}$ \\ ${ }^{1}$ Program Studi Pendidikan Biologi, Fakultas Keguruan dan Ilmu Pendidikan Universitas \\ Muhammadiyah Prof. DR. Hamka Jakarta, Indonesia \\ *Korespondensi : luthpi_safahi@uhamka.ac.id
}

\begin{abstract}
Abstrak
Penelitian yang menggunakan metode Quasi Eksperimen ini bertujuan untuk mengetahui pengaruh penggunaan model pembelajaran Learning Cycle terhadap kemampuan berpikirkritis mahasiswa dalam matakuliah Vertebrata. Metode yang digunakan dalam penelitian ini adalah Quasy Experiment dengan desain penelitian Pre-test Post-test Control Group Design.Sampel penelitian ini adalah mahasiswa Program Studi Pendidikan Biologi semester IV yang diambil dengan menggunakan teknik Cluster Random Sampling. Penguasaan kemampuan berpikir kritis diukur dengan menggunakan tes uraian materi klasifikasi chordata dan pisces sebanyak enam soal, masing-masing mengukur ketercapaian enam indikator kemampuan berpikir kritis. Hasil penelitian menunjukkan bahwa nilai rata-rata posttest kemampuan berpikir kritis kelas eksperimen memperoleh nilai 61,87 sedangkan kelas kontrol memperoleh nilai 49,55. Uji hipotesis menggunakan uji-t pada taraf signifikansi $\alpha=1 \%$ diperoleh nilai Sig.(1-tailed $)=0.000<\mathrm{p} .0 .01$, yang berarti H0 ditolak. Sehingga dapat disimpulkan penggunaan model pembelajaran learning cycle sangat berpengaruh terhadap keterampilan berpikir kritis.
\end{abstract}

Kata kunci: Learning Cycle, Berpikir Kritis

\begin{abstract}
This research use Quasi Experimental method is aimed to know the effect of using of Learning Cycle learning model toward students critical thinking ability in Vertebrata subject. The method used in this study is Quasy Experiment with a Post-test Pre-test Control Group design. The sample of this study is the fourth semester students of Biology Education Study Program selected by using Cluster Random Sampling technique. The mastery of critical thinking ability is measured by using a description of chordata and pisces classification material consist of 6 test items, each of them measuring the achievement of six indicators of critical thinking ability. The results showed that the mean value of critical thinking ability Post-test of experimental class got 61,87 value while the Control class got 49,55 value. The hypothesis testing used the t-test at a significance level $\alpha=1 \%$ obtained the value of Sig. (1-tailed) $=0.000<p .0 .01$, which means that HO is rejected. So it can be concluded that the using of learning cycle learning model is very influential toward critical thinking skills.
\end{abstract}

Keywords: Learning Cycle, Critical Thinking 


\section{PENDAHULUAN}

Biologi merupakan bagian dari ilmu pengetahuan alam (IPA). Pada hakikatnya IPA atau Sains terdiri atas kumpulan produk ilmiah dan serangkaian proses ilmiah. Produk IPA meliputi fakta, konsep, prinsip serta teori. Sedangkan proses yang dilakukan para ilmuwan untuk mempelajari alam ini adalah prosedur empirik dan analitik (Iskandar dan Hidayat, 1997). Interaksi di antara kedua komponen Sains tersebut sangat erat dan tidak dapat dipisahkan. Produk ilmiah yang dihasilkan dari proses ilmiah pada gilirannya akan menjadi dasar bagi proses ilmiah berikutnya untuk menghasilkan produk ilmiah yang baru. Sebuah kontinuitas yang tidak pernah putus, sehingga menjadikan Sains sebagai disiplin ilmu yang sangat dinamis. Rangkaian kegiatan ini selaras dengan prinsip kontrukstivisme, di mana pengetahuan baru dibangun melalui proses kognitif dengan landasan pengetahuan yang sudah ada.

Mengacu pada filsafat konstruktivisme, mahasiswa merupakan pembelajar aktif yang mengkonstruksi sendiri pengetahuannya. Mahasiswa diberi kesempatan untuk berinteraksi langsung dengan obyek belajar, mengamati, mengembangkan pertanyaan, menghubungkan fakta dengan sumber pengetahuan, mengambil kesimpulan, dan mengkomunikasikan. Guru menjadi fasilitator agar pengalaman belajar di atas dapat berhasil dilaksanakan.

Penggunaan model pembelajaran Learning Cycle dalam pembelajaran IPA akan memberikan keterampilan-keterampilan, pengalaman, menemukan sendiri, dan membangun pengetahuannya dari pembelajaran secara alamiah dari lingkungan kelas, keluarga, dan masyarakat serta belajar memecahkannya dengan situasi yang menyenangkan. Penggunaan model-model pembelajaran yang menempatkan aktivitas mahasiswasebagai yang utama, lebih banyak memberikan kesempatan kepada mahasiswa untukbersentuhan denganberbagai objek belajar, dan adanya hubungan baik antara guru danmahasiswa, dapat meningkatkan keterampilanberpikir tingkat tinggi mahasiswa dan mendorongpenggunaan analitis kritis dan partisipasi aktif mahasiswa (Haryono, 2006).

Salah satu bagian dari kemampuan berpikir tingkat tinggi adalah kemampuan berpikir kritis. Menurut Liliasari (2006) berdasarkan prosesnya berpikir dapat dikelompokkan dalam berpikir dasar dan berpikir kompleks. Proses berpikir kompleks yang disebut berpikir tingkat tinggi meliputi pemecahan masalah, pengambilan keputusan, berpikir kritis dan berpikir kreatif. Menurut Rusyana dan Nuryani (2011) keterampilan berpikir bersekor 2, maka mereka termasuk tingkat superior berpikir kreatif. Seseorang yang memiliki superior berpikir kreatif 
mengindikasikan bahwa dia memerlukan kerja keras untuk bisa memiliki kemampuan berpikir kritis.

\section{METODE PENELITIAN}

Metode penelitian yang digunakan adalah quasi eksperimen, karena dalam desain ini mempunyai kelompok kontrol tetapi tidak dapat berfungsi sepenuhnya untuk mengontrol variabel-variabel luar yang mempengaruhi pelaksanaan eksperimen (Sugiyono, 2008). Desaign penelitian menggunakan Pre-test Post-test Control Group Design. Populasi dalam penelitian ini adalah mahasiswa Semester IV Program Studi Pendidikan Biologi FKIP UHAMKA, sebanyak 115 orang yang terbagi dalam 4 kelas, IVA, IVB, IVC dan IVD. Pengambilan sampel pada penelitian ini dilakukan secara naturally formed intact groupdengan menggunakan teknik cluster random sampling, dari teknik tersebut sampel dalam penelitian ini diperoleh sebanyak 61 orang.

Pengumpulan data diperoleh dari hasil tes kemampuan berpikir kritis yang diberikan setelah (posttest) seluruh proses belajar mengajar berlangsung.Penguasaan berpikir kritis diukur dengan menggunakan tes uraian materi klasifikasi chordata dan pisces sebanyak enam soal, masing-masing mengukur ketercapaian enam indikator kemampuan berpikir kritis. Analisis data menggunaka uji-t dan statistika deskriptif menggunakan program SPSS-17.0.

\section{HASIL DAN PEMBAHASAN}

Kemampuan berpikir kritis mahasiswa yang menggunakan model pembelajaran Learning Cycle (kelas eksperimen, n=33) tergolong cukup dengan nilai rata-rata 61,87 dengan simpangan baku sebesar 12,85. Adapun mahasiswa yang belajar dengan model konvensional (kelas kontrol, $\mathrm{n}=28$ ) memiliki kemampuan berpikir kritis yang lebih rendah dengan nilai rata-rata 49,55 dan simpangan baku 12,02.

Apabila kemampuan responden pada kelas eksperimen dan kelas kontrol dibandingkan, secara keseluruhan tampak kemampuan setiap komponen berpikir kritis siswa dari kelompok kontrol lebih rendah dibandingkan kelompok eksperimen. 


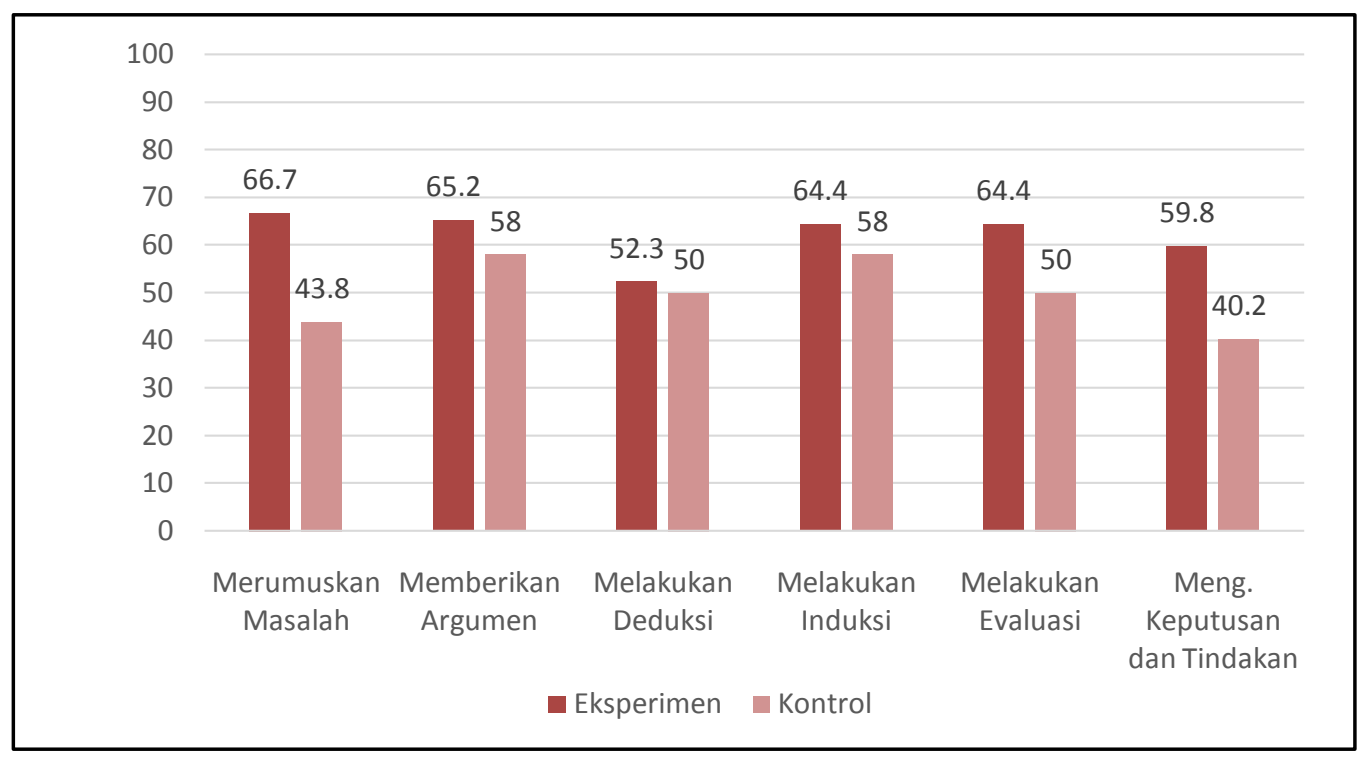

Gambar 1. Perbandingan kemampuan berpikir kritis kelas eksperimendan kontrol

Selain membandingkan persentase rata-rata kemampuan berpikir masing-masing responden, analisis statistik uji rata-rata juga dilakukan untuk melihat apakah ada perbedaan yang signifikan terhadap kemampuan berpikir kritis. Hasil analisis menunjukkan bahwa kemampuan berpikir kritis kelas eksperimen menunjukkan perbedaan yang signifikan pada kemampuan merumuskan msalah, melakukan evaluasi, serta mengambil keputusan dan tindakan. Hasil perhitungan rata-rata kemampuan berpikir kritis responden pada setiap komponen indikator disajikan pada tabel berikut.

Tabel 1. Hasil uji rata-rata kemampuan berpikir kritis setiap indikator

\begin{tabular}{cccc}
\hline Indikator & Probabilitas & $\begin{array}{c}\text { Signifikansi } \\
\boldsymbol{\alpha}=\mathbf{0 , 0 1}\end{array}$ & Keputusan \\
\hline Merumuskan Masalah & 0.000 & $0.00<0.01$ & $\begin{array}{c}\text { Berbeda sangat nyata } \\
\text { (signifikan) }\end{array}$ \\
\hline Memberikan Argumen & 0.234 & $0.234>0.01$ & $\begin{array}{c}\text { Tidak berbeda nyata (tidak } \\
\text { signifikan) }\end{array}$ \\
\hline Melakukan Deduksi & 0.570 & $0.570>0.01$ & $\begin{array}{c}\text { Tidak berbeda nyata (tidak } \\
\text { signifikan) }\end{array}$ \\
\hline Melakukan Induksi & 0.306 & $0.306>0.01$ & $\begin{array}{c}\text { Tidak berbeda nyata (tidak } \\
\text { signifikan) }\end{array}$ \\
$\begin{array}{c}\text { Melakukan Evaluasi } \\
\text { Mengambil Tindakan dan } \\
\text { Keputusan }\end{array}$ & 0.01 & $0.01 \leq 0.01$ & $\begin{array}{c}\text { Berbeda sangat nyata } \\
\text { (signifikan) }\end{array}$ \\
\hline $\begin{array}{c}\text { Meprata } \\
\text { (signifikan) }\end{array}$ \\
\hline
\end{tabular}


Penggunaan model pembelajaran Learning Cycle dinyatakan berbeda untuk kemampuan berpikir kritis mahasiswa apabila terdapat perbedaan yang bermakna pada nilai rata-rata parameter tersebut dari kelompok eksperimen dan kelompok kontrol. Untuk itu dilakukan serangkaian langkah analisa data yang terdiri atas uji prasyarat analisis data berupa uji normalitas distribusi kedua kelompok data yang dilanjutkan dengan uji homogenitas variansi, serta uji hipotesis dengan menggunakan uji t.

Untuk mengetahui normalitas distribusi data dari kedua kelompok dilakukan pengujian dengan menggunakan uji Kolmogorov-Smirnov Z (K-S Z). Hasil pengolahan data melalui Teknik SPSS-17.0 menunjukkan populasi skor kemampuan berpikir kritis secara keseluruhan berdistribusi normal dengan signifikasi sebesar 0,030.

Selanjutnya dilakukan uji homogenitas varians data skor kemampuan berpikir kritis baik kelompok eksperimen dan kontrol dengan menggunakan uji levene juga melalui Teknik SPSS-17.0. Uji ini dimaksudkan untuk melihat ada tidaknya perbedaan varians dari kedua kelompok penelitian. Dari langkah tersebut diperoleh nilai signifikansi sebesar 0,709 yang berarti bahwa skor kemampuan berpikir kritis dari kedua kelompok memiliki variansi yang homogen. Selanjutnya dilakukan uji hipotesis dengan menggunakan uji t. Hasilnya ditampilkan sebagai berikut.

Tabel 2. Ringkasan hasil uji beda rata-rata kemampuanberpikir kritis dengan Uji t

\begin{tabular}{|c|c|c|c|c|}
\hline \multirow{2}{*}{ Model Pembelajaran } & \multicolumn{4}{|c|}{ Skor Kritis } \\
\hline & Rerata & $\mathrm{t}$ & Sig.(1-tailed) & Ho \\
\hline Learning Cycle & 61,87 & 2042 & 000 & to \\
\hline Kontrol & 49,55 & 3.842 & .000 & tolak \\
\hline
\end{tabular}

Uji hipotesis dengan menggunakan Uji t menunjukkan kedua persentase rata-rata berbeda pada taraf signifikansi 1\%. Dengan demikian hipotesis nihil yang menyatakan "tidak ada perbedaan kemampuan berpikir kritis mahasiswa dengan model pembelajaran learning cycle dibandingkan dengan model konvensional" ditolak, dan hipotesis alternatif $\left(\mathrm{H}_{1}\right)$ diterima. Ada perbedaan kemampuan berpikir kritis mahasiswa dengan model pembelajaran learning cycle dibandingkan dengan model konvensional.

Pada semua indikator kemampuan berpikir kritis, mahasiswa yang mendapatkan model pembelajaran Learning Cycle dalam Matakuliah Vertebrata memiliki kemampuan yang lebih baik dibanding kelompok kontrol. Utamanya pada kemampuan merumuskan masalah, 
melakukan evaluasi, serta mengambil keputusan dan tindakan. Penggunaan model pembelajaran Learning Cycle banyak melibatkan kelompok eksperimen di dalam interaksi sosial dalam kelompok. Menurut Vigotsky, interaksi sosial dengan teman lain melalui kerja kelompok memacu terbentuknya ide dan memperkaya perkembangan mental anak, sehingga membuat proses berpikir menjadi terbuka bagi seluruh anak (Santoso, 2007).

Tahapan pembelajaran Learning Cycle meliputi engagement, eksplorasi, eksplanasi, elaborasi dan evaluasi. Pembiasaan mahasiswa untuk secara konsisten melaksanakan tahapantahapan tersebut memberi kontribusi pada diperolehnya kemampuan berpikir kritis yang lebih baik yaitu (kelas eksperimen, $\mathrm{n}=33$ ) tergolong cukup dengan nilai rata-rata 61,87 dengan simpangan baku sebesar 12,85. Adapun mahasiswa yang belajar dengan model konvensional (kelas kontrol, $\mathrm{n}=28$ ) memiliki kemampuan berpikir kritis yang lebih rendah dengan nilai rata-rata 49,55 dan simpangan baku 12,02. Hasil penelitian ini mendukung hasil penelitian serupa terdahulu, Agustini (2010) terdapat perbedaan yang signifikan prestasi belajar antara siswa yang belajar menggunakan Learning Cycle Model (LCM) dengan siswa yang belajar menggunakan model konvensional, prestasi belajar siswa kelompok LCM lebih tinggi daripada kelompok konvensional dan Pembelajaran model LCM lebih efektif daripada model konvensional dalam peningkatan prestasi belajar siswa. Mengembangkan kemampuan berpikir kritis memerlukan latihan dalam waktu yang cukup. Kemampun berpikir kritis akan mengalami perkembangan sesuai bentuk latihan dan tuntutan berpikirnya, untuk itu sekolah (pembelajaran) harus membelajarkan siswa berpikir (Santoso, 2007).

Beberapa indikator berpikir kritis merupakan tahapan dari Learning Cycle. Inti berpikir kritis adalah deskripsi yang rinci dari sejumlah karakteristik yang berhubungan, yang meliputi analisis, inferensi, eksplanasi, evaluasi, pengaturan diri, dan interpretasi (Liliasari, 2010). Tahap engagement atau tahap membangkitkan dan mengembangkan minat dan keingintahuan peserta didik, memberi arah pada mahasiswa tentang tujuan pembelajaran. Tujuan yang jelas mengenai kegiatan belajar yang dilakukannya akan memacu keterlibatan semua aspek intelektual mahasiswa, sehingga memberi peluang yang lebih terbuka dalam mencapai kemampuan berpikir yang lebih tinggi sekalipun. Penggunaan model pembelajaran Learning Cycle menunjukkan hasil tersebut yakni kemampuan merumuskan masalah (66,7\%), memberikan argumen (65,2\%). Motivasi akan dirangsang karena adanya tujuan. Jadi motivasi dalam hal ini sebenarnya merupakan respons dari suatu aksi yakni tujuan (Sardiman, 1990). Menurut Purwanto (1998) motivasi adalah pendorong suatu usaha yang disadari untuk 
mempengaruhi tingkah laku seseorang agar ia menjadi tergerak hatinya untuk bertindak melakukan sesuatu sehingga mecapai hasil atau tujuan tertentu.

Tahap eksplorasi pada matakuliah Vertebrata menghadapkan mahasiswa pada sejumlah objek dan sumber belajar yang harus dikaji, diamati, di-inferensi dan diklasifikasi secara berkelompok. Objek dan sumber belajar tersebut berupa gambar-gambar chordata dan pisces serta bahan bacaan mengenai organisme yang tergolong vertebrata. Muara dari kegiatan ini adalah terbangunnya konsep atau pengetahuan baru pada struktur kognitif mahasiswa yang dituangkan dalam bentuk laporan hasil eksplorasi dalam bentuk presentasi di depan kelas. Proses eksplorasi ini lebih terarah karena diawali oleh pertanyaan yang jawabannya harus diperoleh pada akhir penggalian fakta dan konsep. Pada pertemuanpertemuan awal matakuliah, pertanyaan penuntun diajukan oleh dosen pengampu mata kuliah. Selanjutnya, mahasiswa diberi kesempatan untuk menyusun sendiri pertanyaan penuntun kegiatan eksplorasi tersebut. Dalam hal ini Nuryani (2007) mengatakan salah satu aspek yang berperan dalam penggunaan keterampilan proses yaitu melakukan eksplorasi materi dan fenomena. Pengalaman langsung tersebut memungkinkan siswa untuk menggunakan alat-alat inderanya dan mengumpulkan informasi atau bukti-bukti untuk kemudian ditindaklanjuti dengan pengajuan pertanyaan, merumuskan hipotesis berdasarkan gagasan yang ada. Kebiasaan ini membangun kemampuan mahasiswa dalam merumuskan masalah seperti pada hasil penelitian yang diperoleh yaitu sebesar $66,7 \%$.

Pada tahap eksplanasi pembelajaran Learning Cycle, peserta didik diminta untuk menjelaskan suatu konsep dengan kalimat/pemikiran sendiri. Penjelasan tersebut akan disertai permintaan bukti dan klarifikasi (Wena, 2009). Dalam perkuliahan vertebrata pada penelitian ini, tahap eksplanasi Learning Cycle diisi dengan presentasi kelompok-kelompok kerja mahasiswa yang melaporkan hasil eksplorasinya. Selanjutnya mahasiswa lain memberi tanggapan dan pertanyaan sebagai bentuk klarifikasi, yang direspon oleh kelompok penyaji dengan memberikan argumentasi. Bentuk-bentuk kegiatan demikian merupakan latihan bagi mahasiswa untuk menunjang pemilikan kemampuan melakukan deduksi dan memberikan argumentasi, sebagai bagian dari kemampuan berpikir kritisnya.

Kemampuan melakukan induksi meliputi kemampuan menganalisis data, membuat generalisasi dan menarik kesimpulan (Arnyana, 2004).Serangkaian kemampuan ini merupakan kemampuan peserta didik dalam menggunakan fakta, konsep atau pengetahuan yang baru diterimanya untuk membangun pengetahuan atau pemahaman yang lebih luas. 
Pengembangan kemampuan yang bersifat aplikatif ini pada pembelajaran Learning Cycle terletak padatahap elaborasi. Menurut Wena (2009) pada tahap elaborasi peserta didik menerapkan konsep dan keterampilan yang telah dipelajari dalam situasi baru atau konteks yang berbeda. Dengan demikian peserta didik akan dapat belajar secara bermakna, karena telah dapat menerapkan/mengaplikasikan konsep yang baru dipelajarinya dalam situasi baru.

Tahap evaluasi pembelajaran Learning Cycle memberi ruang pada peserta didik untuk dapat melakukan evaluasi diri dengan mengajukan pertanyaan terbuka dan mencari jawaban yang menggunakan observasi, bukti, dan penjelasan yang diperoleh sebelumnya. Melalui tahap ini peserta didik juga akan dapat mengetahui kekurangan atau kemajuan dalam proses pembelajaran yang sudah dilakukannya, untuk menjadi dasar bagi pengambilan langkah lebih lanjut.Menurut Ennis berpikir kritis adalah suatu proses berpikir yang bertujuan untuk membuat keputusan yang rasional yang diarahkan untuk memutuskan apakah meyakini atau melakukan sesuatu (Noviani, 2010). Manfaat dari pengalaman yang diperoleh mahasiswa melalui tahapan ini tampak dari kemampuan melakukan evaluasi serta kemampuan mengambil keputusan dan tindakan yang lebih baik dibandingkan mahasiswa yang tidak mengalaminya pada kelas kontrol.

\section{KESIMPULAN}

Penggunaan model pembelajaran Learning Cyclelebih baik digunakan untuk kemampuan berpikir kritis mahasiswa dibandingkan dengan model konvensional pada perkuliahan vertebrata, dan $\mu_{\text {Eksperimen }}(61,87)>\mu_{\text {Kontrol }}(49,55)$.

\section{REFERENSI}

Arnyana, I.B.P. 2004. Pengembangan Perangkat Model Belajar Berdasarkan Masalah Dipandu Strategi Kooperatif serta Pengaruhnya terhadap Kemampuan Berpikir Kritis dan Hasil Belajar Siswa Sekolah Menengah Atas pada Pelajaran Ekosistem. Disertasi. Universitas Negeri Malang. Malang.

Haryono, 2006. Model Pembelajaran Berbasis Peningkatan Keterampilan Proses Sains. Jurnal Pendidikan Dasar. Vol. 7(1): 1-13. 
Iskandar, S.M. dan Hidayat, E.M. 1997. Pendidikan Ilmu Pengetahuan Alam. Departemen Pendidikan dan Kebudayaan, Jakarta.

Liliasari. 2010. Berpikir kritis dalam Pembelajaran Sains Kimia Menuju Profesionalitas Guru. Jurnal Program Studi pendidikan IPA SPs UPI. Bandung. Tersedia: http://file.upi.edu/Direktori/SPS/PRODI.PENDIDIKAN_IPA/194909271978032LILIASARI/BERPIKIR_KRITIS_Dlm_Pembel_09.pdf

Liliasari. 2006. Peningkatan Kualitas Guru Sains Melalui Pengembangan Kemampuan Berpikir Tingkat Tinggi. Jurnal Program Studi Pendidikan IPA SPs UPI. Bandung. Tersedia:http://file.upi.edu/Direktori/SPS/PRODI.PENDIDIKAN_IPA/1949092719 78032-LILIASARI/makalah_UPSI_2006_Liliasari.pdf

Noviani, L. 2010. Peningkatan Kemampuan Berpikir Kritis Melalui Integrated LearningPada Mata Pelajaran IPS SMP Integrated Learning.Jurnal Paedagogia. Vol. 13(2):173 187.

Nuryani R. 2007. Keterampilan Proses Sains. Sekolah Pasca Sarjana Universitas Indonesia. Bandung.

Purwanto, N. 1998. Psikologi Pendidikan. PT. Remaja Rosda Karya. Bandung.

Rusyana, A dan Nuryani Y. R. 2011. Pengembangan Program Perkuliahan Zoologi Invertebrata Berbasis Keterampilan Berpikir Kritis-Kreatif.Prosiding Seminar Nasional Pendidikan 2011. UNILA. Lampung.

Santoso, H. 2010. Pengaruh Cooperative Learning Dipandu Inquiry Terhadap Kemampuan Berpikir Kritis Siswa SMA Berkemampuan Atas dan Bawah di Kota Metro. Pendidikan Biologi FKIP Universitas. Jurnal Bioedukasi. Vol. 1(2):193. DOI: http://dx.doi.org/10.24127/bioedukasi.v1i2.193

Sardiman A.M. 1990. Interaksi dan Motivasi Belajar Mengajar. C.V. Rajawali, Jakarta.

Sugiyono, 2008. Metode Penelitian Kuantitatif, Kualitatif, dan R\&D. Alfabeta, Bandung.

Wena, M. 2009. Strategi Pembelajaran Inovatif Kontemporer Suatu Tinjauan Konseptual Operasional. Bumi Aksara, Jakarta. 